\title{
ANTI-DIABETIC EFFECT OF MORINGA OLEIFERA EXTRACT ON PAROTID GLAND OF ALBINO RATS
}

\author{
Sally H. Abo Baker* and Amira A. R. Moawad*
}

\begin{abstract}
Aim: to investigate the antidiabetic effect of moringa oleifera on parotid gland.

Materials and methods: 45 adult male albino rats weighing from 150-200 gm were used in this study. The rats were divided into three equal groups (15 rats each) as follow: Group I: The animals served as control group. Group II: The animals subjected to diabetic induction and did not receive any treatment. Group III: The animals subjected to diabetic induction, soon after blood analysis, animals of this group were given $200 \mathrm{mg} / \mathrm{kg}$ body wt. /day of moringa oleifera extract by gastric tube for 3 weeks. At the end of the moringa treatment, the rats were euthanized with over dose halothane and parotid glands were rapidly excised, then processed for: histological examination using heamatoxylin and eosin stain, transmission electron microscope and comet assay.
\end{abstract}

Results: the examination with light microscope showed group I with normal architecture of the glandular tissue, the parotid gland sections showing densely packed acinar cells with large basally located nuclei while in group II parotid gland sections showed loss of acinar outlines with intracellular vacuolization and pyknotic nuclei. In-group III the acinar cells begin to regain their symmetrical shape and size. Ultrastructurely the serous cell of group I showed euchromatic nuclei, parallel cisternae rough endoplasmic reticulum, homogenous secretory granules and intact desmosomal attachments between cells. The serous cell of group II showing irregular nuclear membrane with predominant heterochromatin, dilated and irregular arrangements of rough endoplasmic reticulum and multiple vacuoles. In-group III the serous acini appeared with less number of vacuoles and numerous parallel cisternae of rough endoplasmic reticulum. The Comet assay results: In the control parotid glands, the majority of the cells appeared as homologous discs with a very low tail moment, very low percentage of tail length and tail DNA \%. In group II tail formation was different from the normal gland cells in the number of tailed cells and the tail length. In group III the tail moment was found to be significantly decreased than that found in the group II.

Conclusion: These results help to increase information about the usefulness of M. oleifera and its safety.

KEYWORDS: Moringa oleifera, Comet assay, parotid gland, Transmission electron microscope

\footnotetext{
* Lecturer of Oral Biology Department, Faculty of Dentistry, Mansoura University, Egypt
} 


\section{INTRODUCTION}

Diabetes Mellitus (DM) is one of the most common chronic, metabolic and endocrine disorder. It is defined as elevation in blood glucose level as a result of inadequate insulin release from pancreas's Langerhans islets or another cause which is insulin resistance in peripheral tissues. In diabetes mellitus, hyperglycemic effects cause many drawbacks, which affect structure of systems, organs or tissues ${ }^{1}$.

Many complications in organs such as kidneys, eyes, heart and salivary glands can happen due to diabetes mellitus, ${ }^{2}$. Several techniques have caused experimental diabetes mellitus in laboratory animals, one of which is injection of drugs such as streptozotocin or alloxan. These materials eventually inflate and degenerate the beta cells of the Langerhans islets, ${ }^{3}$. Parotid glands affected by diabetes as a result of oral infection due to xerostomia, ${ }^{4}$.

Dietary glycemic control is required to prevent or limit the effects of DM. use of dietary components that contains bioactive compounds obtained from crops used as ingredients can therefore be used as dietary supplements due to their beneficial impacts, ${ }^{5}$.

Moringa oleifera (MO) "drum stick tree" belongs to the Moringaceae family. This tree is essential because it has medicinal uses for its flowers, pods and leaves, ${ }^{6}$. Moringa leaf is a prospective source of natural antioxidants such as total phenolics and antioxidant vitamins $\mathrm{A}, \mathrm{C}$ and $\mathrm{E}$, polyphenol oxidase, ascorbic acid oxidase, and catalase, ${ }^{7}$. It has been revealed that Moringa leaves behave as a hypocholesterolemic agent, antidiabetic agent, hypotensive agent, thyroid hormone regulator, and antitumor agent. ${ }^{8}$.

\section{MATERIAL AND METHODS}

45 adult male albino rats weighing from 150-200 gm. were used in this study. The animals were fed a standard diet and free access to water. The rats were divided into three equal groups (15 rats each) as follow:
Group I: The animals served as control group

Group II: The animals subjected to diabetic induction and did not receive any treatment.

Group III: The animals subjected to diabetic induction, soon after blood analysis, animals of this group were given $200 \mathrm{mg} / \mathrm{kg}$ body wt. /day of moringa oleifera extract by gastric tube for 3 weeks. (dose, source, preparation), ${ }^{9}$.

\section{Diabetes induction:}

Experimental diabetes was induced to all animals of group II, III after overnight starvation by a single intraperitoneal injection of streptozotocin (STZ: 45 $\mathrm{mg} / \mathrm{kg}$ body weight in $0.1 \mathrm{ml}$ citrate buffer, $\mathrm{pH} 4.5$ ), ${ }^{10}$. After 3 days of STZ injection the diagnosis of diabetes was based on hyperglycemia (non-fasting blood glucose level more than $300 \mathrm{mg} / \mathrm{dl}$ ) using blood glucose meter, ${ }^{11}$. The blood glucose level and the body weight of the rats were monitored every week and the results were listed in table $(1 \& 2)$. Statistical analysis for blood glucose level and body weight of all animals was made. Streptozotocin obtained from (Sigma chemical co., St Louis, Mo, USA)

At the end of the moringa treatment, the rats were euthanized with over dose halothane and parotid glands were rapidly excised, fixed in $10 \%$ neutral buffered formalin for 24 hours then processed for:

1. Routine histological examination using heamatoxylin and eosin stain

2. Transmission electron microscope examination.

For single cell gell electrophoresis study (comet assay): After excision of parotid glands specimens were preserved in $1 \mathrm{ml}$ saline solution in an eppendorf and were kept frozen at $-180 \mathrm{c} .{ }^{12,13}$.

\section{Comet assay methodology, ${ }^{12,13}$.}

The basic steps of the assay include:

- Preparation of the samples

- Preparation of the microscopically slide. 
- Decomposition of the cells to liberate DNA

- Exposure to alkali ( $\mathrm{pH}>13$ ) to obtain single stranded DNA.

- Electrophoresis under alkaline $\mathrm{pH}(\mathrm{pH}>13)$

- Neutralization of alkali.

- DNA staining and comet visualization

- Comet scoring.

1- Preparation of the samples:

- The frozen samples were crushed.

- Each $1 \mathrm{~g}$ of crushed samples added to $1 \mathrm{ml}$ icecold PBS then stirred for 5 min and filtered.

- this suspension $(100 \mu \mathrm{l})$ then mixed with 600 $\mu \mathrm{l}$ of low-melting agarose $(0.8 \%$ in PBS). And $100 \mu \mathrm{l}$ of this mixture was spread on precoated slides.

\section{2- Preparation of microscopically slide:}

- Fully frosted slides were used for more stability of the agarose.

- The number of the agarose layers should be from one to three. In the two layer procedures cell contained in agarose are placed on slide pretreated with a layer of normal melting point agarose NMPA 1.0-1.5\%.

- Coverslip was applied to spread out each molten agarose layer.

\section{3- Decomposition:}

- After solidification of agarose gel, slides were placed for at least 2 hours in Decomposition solution $(2.5 \mathrm{~m}$ sodium chloride, $10 \mathrm{~mm}$ Tris, $100 \mathrm{~mm}$ EDTA and freshly before use $1 \%$ Triton X-100 and DMSO $10 \%$ were added).

\section{4- Unwinding:}

- Prior to electrophoresis, the slides were incubated in alkaline buffer $(\mathrm{pH}>13)$ for $20-60$ min. So single stranded DNA will be obtained and alkali-labil sites will be expressed as singlestrand breaks.

- Components of alkaline solution (1mm EDTA and $300 \mathrm{~mm} \mathrm{NAOH}, \mathrm{pH}>13$ ).

\section{5- Electrophoresis:}

- Single-stranded DNA in the gel was electrophoresed under alkaline condition to produce comets. Other electrophoresis condition as $1 \mathrm{volt} / \mathrm{cm}$ and about $300 \mathrm{~mA}$ are adjusted.

\section{6- Neutralization:}

- After electrophoresis, neutralization of the gel by rinsing the slides with suitable buffer (Tris $\mathrm{pH}$ 7.5) for $5 \mathrm{~min}$ three times for $5 \mathrm{~min}$. each.

- Then slides can be stained and comets scored, or allow the gel to be dried, keep slides, and when convenient the comets will be scored.

\section{7- Staining:}

- Before staining slides allowed to be dried by adding absolute ethanol or methanol on it for $5 \mathrm{~min}$.

- Ethidium bromide $20 \mu \mathrm{g} / \mathrm{ml}$ at $4^{\circ} \mathrm{C}$ was applied for staining. Observation must be done when samples still humid and with fluorescence microscope, DNA fragment migration patterns of 100 cells for each dose level was evaluated (With excitation filter 420-490nm).

\section{8-Comet scoring:}

- The measuring of comet tail length will be from the middle of the nucleus to the end of tail., and damaged DNA was detected by using a 40x objective on a fluorescent microscope.

- comet 5 image analysis software was used, Ltd. (Liverpool, UK) linked to a CCD camera to assess the quantitative and qualitative extent of DNA damage in the cells. As a whole, 50 to 100 randomly selected cells are analyzed per sample. 
- Tail moment (numerical measurement of DNA damage) is the product of the length of the "tail" of DNA trailing the nucleus and the percentage of total DNA in the tail. Higher tail moments indicate greater DNA damage. So tail moment will be the parameter used to determine the statistical significance of DNA damage.

\section{Electron microscope preparation ${ }^{14}$}

\section{- Fixation:}

The specimens were dissected rapidly and small pieces of the tissue (not more than 1-2 $\mathrm{mm}$ in thick) were cut and immersed in glutaraldehyde $4 \%$ as a primary fixative at $4^{\circ} \mathrm{C}$. Then were washed by cold sodium phosphate buffer to remove any traces of aldehyde. Osmic acid solution of $1 \%$ was used as a second fixative for a period of one to two hours. Then, were washed by distilled water to remove excess osmic acid.

\section{- Dehydration:}

After fixation the tissue was dehydrated by soaking in a graded series of ethanol alcohol.

\section{- Infiltration:}

propylene oxide was used for specimen infiltration starting with (1:1) then continued with (1:3 propylene oxide: embedding mixture) all the night at room temperature.

\section{- Embedding:}

Was done in freshly prepared plastic embedding mixture in pre-dried capsules for one to two h.

\section{- Polymerization:}

$60^{\circ} \mathrm{C}$ polymerization of capsules was done for one to two days then cured at room temperature for at least one day before attempting the section.

\section{- Cutting:}

Blocks were trimmed in a trapezoid shape, first of all a semithin sections were cut then an ultrathin section were obtained.
- Semithin sections $(1 \mu \mathrm{m})$ : They were cut with the aid of LKB ultramicrotome and glass knives, than stained with toluidine blue. The sections were examined with the light microscope to determine the spot of choice to be ultracut for electron microscope examination.

- Ultrathin section $(50 \mathrm{~nm})$ : They were cut by means of LKB ultramicrotome, and a sharp new glass Knives. The ultrathin sections were picked on grids and were kept in a Petridish with proper identification.

\section{- Staining the grids:}

The grids were double stained with uranyl acetate and lead citrate.

\section{RESULTS}

Statistical analysis results:

TABLE (1) showing mean \pm SD for blood glucose level after diabetic induction and its statistical analysis results for the different groups:

\section{Blood glucose}

\begin{tabular}{|c|c|c|c|c|c|c|}
\hline & & \multirow{2}{*}{ Group I } & \multirow{2}{*}{ Group II } & \multirow{2}{*}{ Group III } & \multicolumn{2}{|c|}{ ANOVA } \\
\hline & & & & & $\mathrm{F}$ & $\mathrm{P}$ value \\
\hline \multirow{2}{*}{$\begin{array}{l}\frac{y}{J} \\
0 \\
3 \\
0 \\
0\end{array}$} & Mean & $191.67^{\mathrm{A}}$ & 384.25 & $293.33^{\text {АВ }}$ & \multirow{2}{*}{20.08} & \multirow{2}{*}{0.000} \\
\hline & SD & 74.70 & 32.74 & 35.02 & & \\
\hline \multirow{2}{*}{$\begin{array}{l}\tilde{y} \\
\tilde{d} \\
\vdots \\
0 \\
3\end{array}$} & Mean & $196.17^{\mathrm{A}}$ & $436.38^{a}$ & $245.83^{\mathrm{A}}$ & \multirow{2}{*}{14.9} & \multirow{2}{*}{0.000} \\
\hline & SD & 150.16 & 42.27 & 33.37 & & \\
\hline
\end{tabular}

Non-significant: at $P>0.05$.Significant: at $P<0.05$.

$P$ value represent significance between group I, group II and group III groups in different weeks

A = significance between group II and group I or group III (in all weeks groups)

B = significance between group I and group III (in all weeks groups)

a= significance between week One and Other weeks after it (in all groups group I, group II and group III) 
TABLE (2) Showing mean \pm SD for body weight after diabetic induction and its statistical analysis results for the different groups:

\section{Body weight}

\begin{tabular}{|c|c|c|c|c|c|c|}
\hline & & \multirow{2}{*}{ Group I } & \multirow{2}{*}{ Group II } & \multirow{2}{*}{ Group III } & \multicolumn{2}{|c|}{ ANOVA } \\
\hline & & & & & $\mathrm{F}$ & P value \\
\hline \multirow{2}{*}{$\begin{array}{l}\frac{y}{8} \\
0 \\
0 \\
0 \\
0\end{array}$} & Mean & 220.17 & 195.50 & 205.67 & \multirow{2}{*}{3} & \multirow{2}{*}{0.07} \\
\hline & SD & 28.46 & 10.10 & 15.16 & & \\
\hline \multirow{2}{*}{$\begin{array}{l}\tilde{u} \\
\vec{d} \\
\vdots \\
0 \\
0 \\
3\end{array}$} & Mean & $258.67^{\mathrm{Aa}}$ & 185.38 & $213.67^{\mathrm{B}}$ & \multirow{2}{*}{14.8} & \multirow{2}{*}{0.000} \\
\hline & SD & 40.68 & 13.84 & 13.82 & & \\
\hline
\end{tabular}

Non-significant: at $P>0.05$.Significant: at $P<0.05$.

P value represent significance between group I, group II and group III in different weeks

A = significance between group II and group I or group III (in all weeks groups)

B = significance between group I and group III (in all weeks groups)

a= significance between week one and other weeks after it (in all groups group I, group II and group III)

\section{Light microscope results with $\mathbf{H} \&$ E stain}

Group I: showing the normal architecture of the glandular tissue, the parotid gland sections showing densely packed acinar cells with large basally located nuclei. Striated duct with their epithelial lining is shown.

Group II: showing loss of acinar outlines with intracellular vacuolization and pyknotic nuclei. The striated duct has intact cellular lining.

Group III: showing the acinar cells begin to regain their symmetrical shape and size.

\section{Transmission electron microscope results:}

Group I: showed acinar cells with nuclear chromatin distribution and euchromatic nucleus, densely packed electron dense homogenous secretory granules, rough endoplasmic reticulum with condensed aspect and parallel cisternae and intact desmosomal attachments between cells.

Group II: the serous acini appeared with irregular nuclear membrane with predominant heterochromatin, dilated and irregular arrangements of rough endoplasmic reticulum and multiple vacuoles.

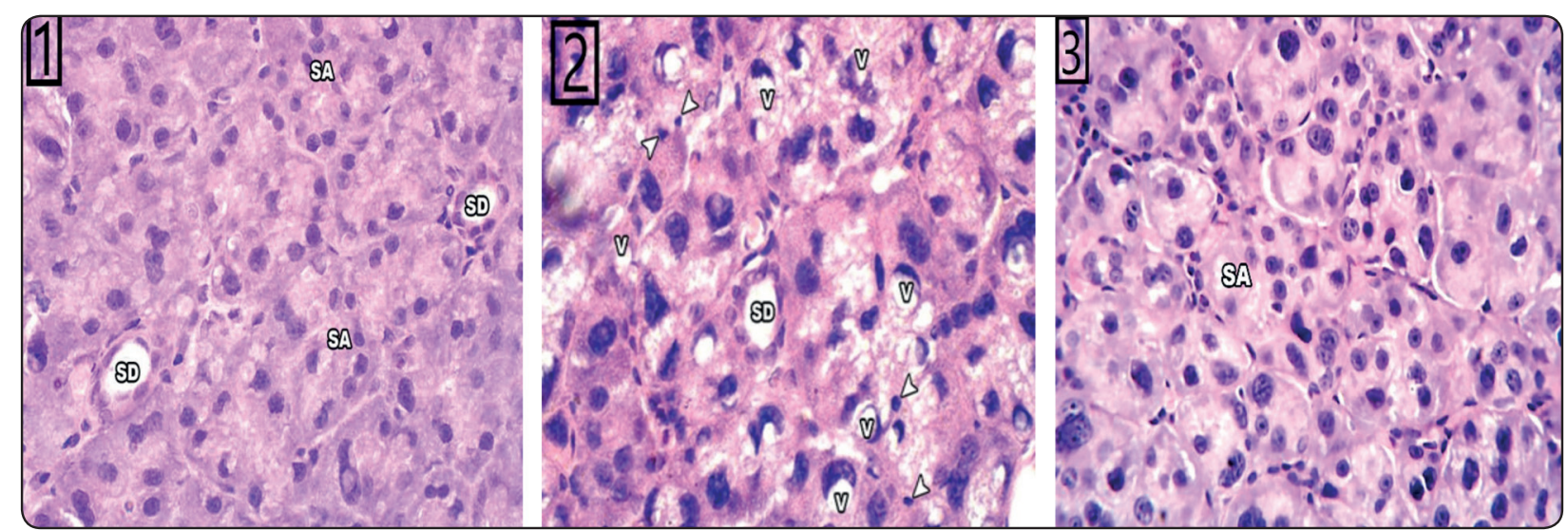

Fig A: (1) Showing group I with normal architecture of the glandular tissue, the parotid gland sections showing densely packed serous acini (SA) with large basally located nuclei. Striated duct with their epithelial lining is shown (SD). (2) Showing group II with loss of acinar outlines with intracellular vacuolization (V) and pyknotic nuclei (arrowhead).The striated duct has intact cellular lining. (3) Showing group III with acinar cells that begin to regain their symmetrical shape and size. (H\&E stain, $\mathrm{x} 400)$ 


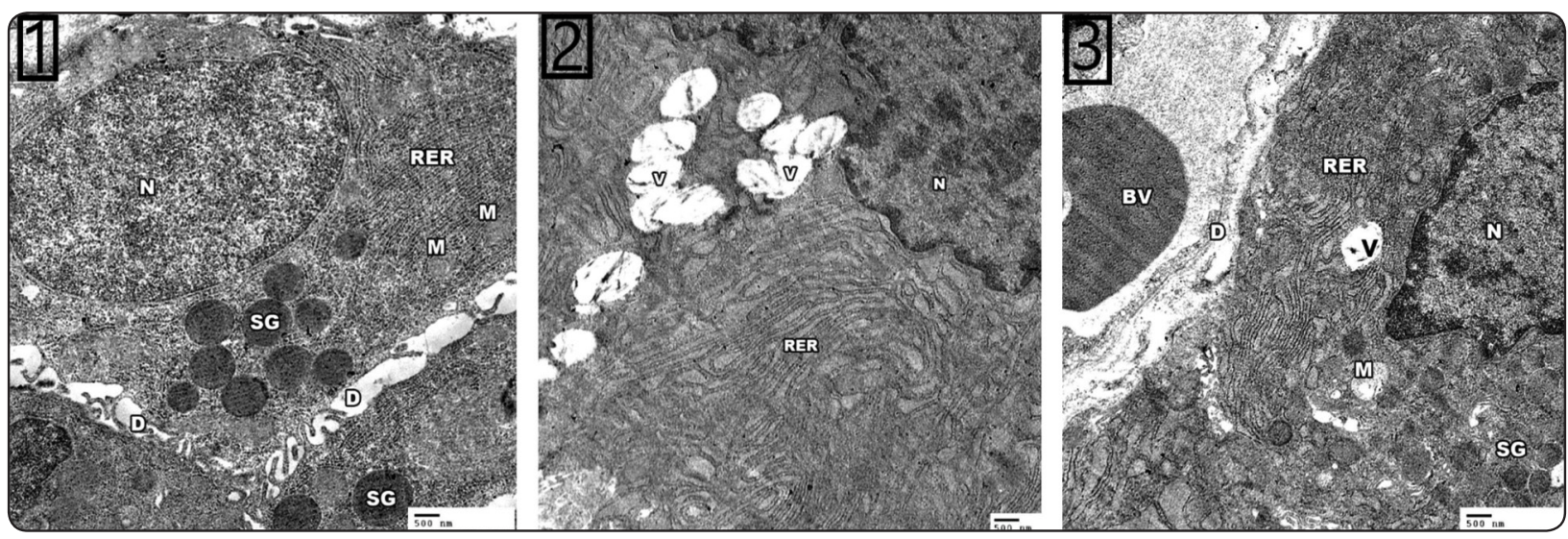

Fig. B: Transmission electron micrographs of parotid glands showing (1) serous cell of group I with euchromatic nuclei (N), parallel cisternae rough endoplasmic reticulum (RER) containing mitochondria (M) in between, homogenous secretory granules (SG) and intact desmosomal attachments(D) between cells. (2) serous cell of group II showing irregular nuclear membrane with predominant heterochromatin $(\mathrm{N})$, dilated and irregular arrangements of rough endoplasmic reticulum (RER) and multiple vacuoles (V). (3) The serous acini of group III appeared with less number of vacuoles and numerous parallel cisternae of rough endoplasmic reticulum. (TM X 3000).
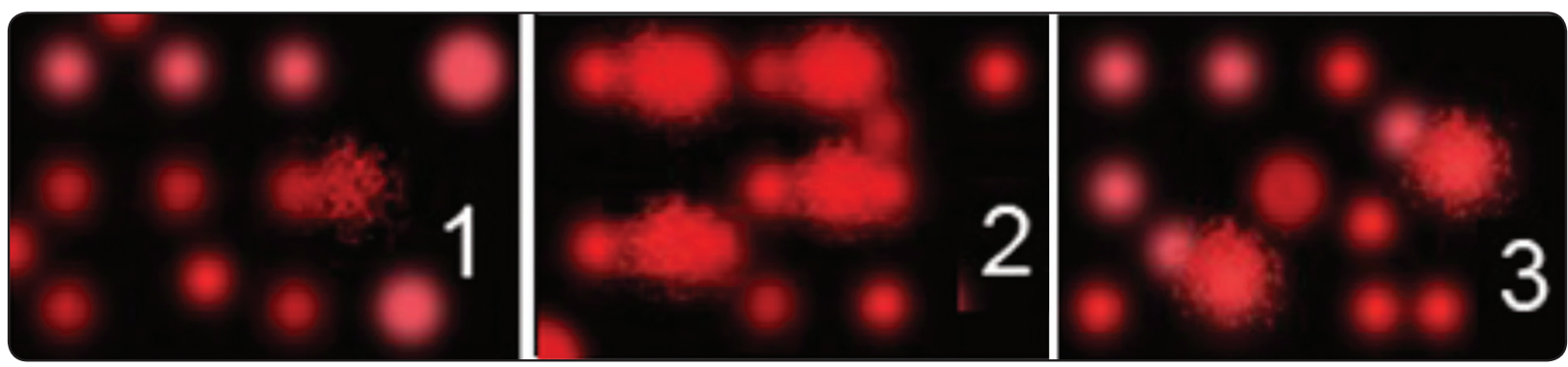

Fig. (C): Photographs of acinar cells observed by Comet assay showing dark red round area representing intact DNA while less dark comet-shaped area close to nucleus representing DNA breaks. (1) representing group I, (2) representing group II and (3) representing group III.

Group III: the serous acini appeared with less number of vacuoles and numerous parallel cisternae of rough endoplasmic reticulum.

\section{The Comet assay results}

Comet assay was performed to analyze the extent of cellular DNA damage in parotid gland cells of all groups. In the control parotid glands, the majority of the cells appeared as homologous discs with a very low tail moment, very low percentage of tail length and tail DNA.

In group II tail formation was different from the normal gland cells in the number of tailed cells and the tail length. In group III the tail moment was found to be significantly decreased than that found in the group II. 


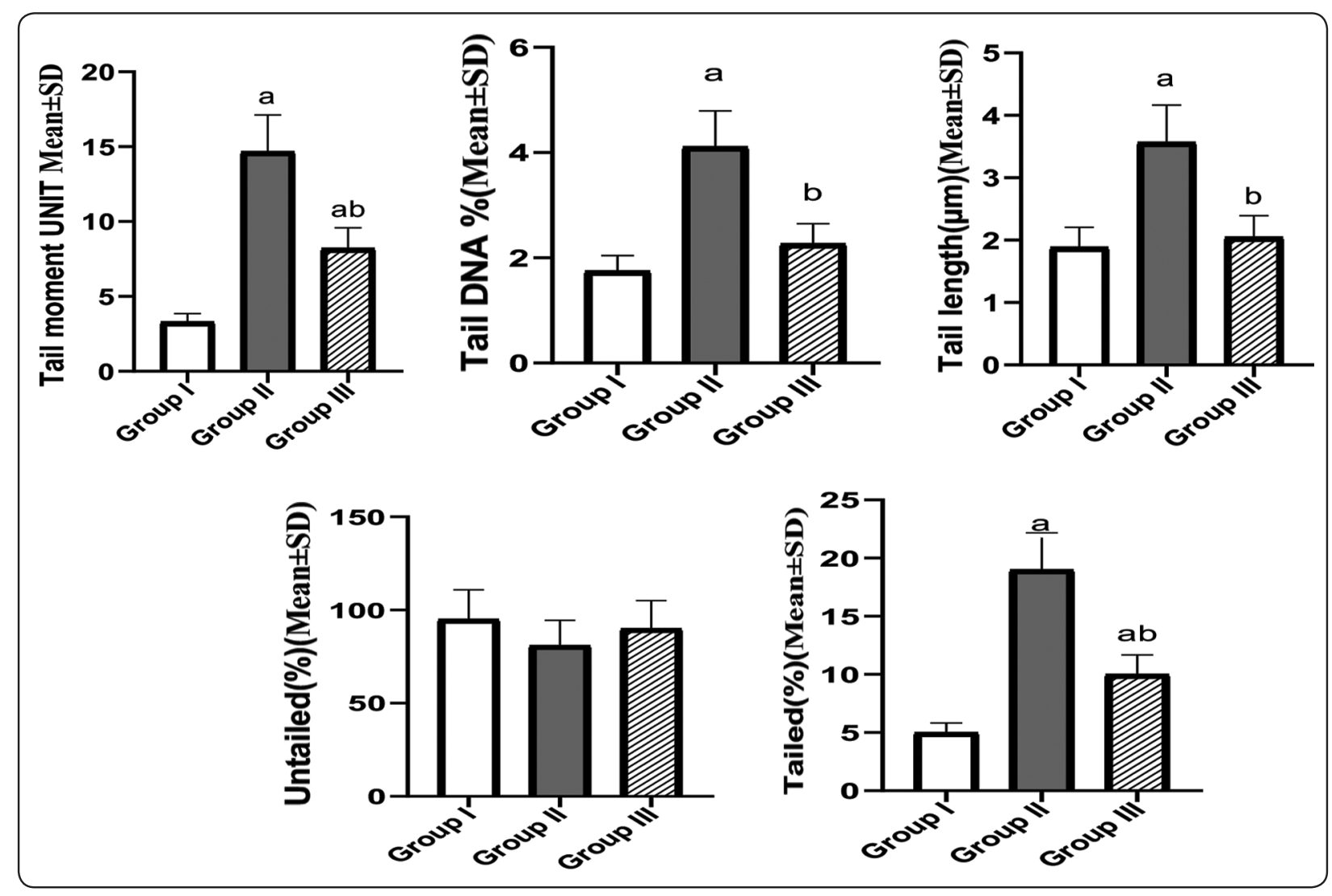

Bar charts showing estimated mean values of comet assay for all groups:

- Tail moment,

- Tail dna $\%$,

- Tail length,

- Untailed and

- Tailed.

TABLE (3) Showing mean \pm SD for comet assay parameters and its statistical significance for the different groups:

\begin{tabular}{|l|c|c|c|}
\hline & Group I & Group II & Group III \\
\hline $\begin{array}{l}\text { Tail moment } \\
\text { UNIT }\end{array}$ & $3.31 \pm 0.55$ & $14.67 \pm 2.45^{\mathrm{a}}$ & $8.22 \pm 1.37^{\mathrm{ab}}$ \\
\hline Tail DNA \% & $1.75 \pm 0.29$ & $4.11 \pm 0.69^{\mathrm{a}}$ & $2.27 \pm 0.38^{\mathrm{b}}$ \\
\hline Tail length( $\boldsymbol{\mu m})$ & $1.89 \pm 0.32$ & $3.57 \pm 0.60^{\mathrm{a}}$ & $2.05 \pm 0.34^{\mathrm{b}}$ \\
\hline Untailed (\%) & $95.00 \pm 15.83$ & $81.00 \pm 13.50$ & $90.00 \pm 15.00$ \\
\hline Tailed (\%) & $5.00 \pm 0.83$ & $19.00 \pm 3.17^{\mathrm{a}}$ & $10.00 \pm 1.67^{\mathrm{ab}}$ \\
\hline
\end{tabular}

Data expressed as mean $\pm S D$

SD: standard deviation P:Probability

Test used: One- way ANOVA followed by post-hoc Tukey

a: significance vs. Control group $(P<0.05)$.

b: significance vs. diabetic $\operatorname{Group}(P<0.05)$.

\section{DISCUSSION}

In experimental and clinical inquiries, DM usually produces changes in cells generally and in salivary parts specifically. Experimentally and in humans, a reduction in salivary flow and salivary elements is generally noted, ${ }^{15}$.

In the present study, the diabetic animals had significant decrease in their body weight. Whereas in animals received moringa oleifera, recovery of decreased weight was observed, these results coincided with Caldeira et al., 2004 who stated that the Diabetes mellitus causes metabolic disorders in distinct organs, including body weight decrease and tissue destruction, ${ }^{16}$.

Also Divi SM et al., 2012 reported that a reduction in blood sugar due to moringa oleifera 
treatment can be observed in various trials in diabetic rats in the form of reduction of $25 \%$ or more on average, ${ }^{17}$.

The light microscopic examination of the parotid glands after diabetic induction in the present study revealed loss of acinar outlines with intracellular vacuolization and the gland begin to regain their symmetrical shape and size after receiving moringa oleifera, these results in agreement with Abir El Sadik et al., 2018 who found in their study after 2 week of diabetic induction that the salivary glands showed damaged effects in acini presented by multiple vacuoles with nucleus displacement while striated ducts presents atrophy and pyknotic nuclei and vacuoles surrounding cells, ${ }^{18}$.

Also A. Villarruel-López et al., 2018 reported that the beneficial effects of moringa leaves are due to its polyphenols content and others useful compounds, ${ }^{6}$.

After diabetic induction in the present study, the ultrastructure of the parotid gland showed that the serous acini appeared with irregular nuclear membrane, dilated and irregular arrangements of rough endoplasmic reticulum and multiple vacuoles.

After receiving moringa oleifera, the serous acini appeared with less number of vacuoles and numerous parallel cisternae of rough endoplasmic reticulum, these results was supported by Abir El Sadik et al., 2018 who found that after 2 week of diabetic induction, the specimens showed absence of mature secretory granules. Cytoplasm showed multiple vacuoles, Pyknotic and irregularly shaped nuclei. Degenerated, swollen and irregular cristae of mitochondria. Irregular, dilated and degenerated rough endoplasmic reticula in cytoplasm, ${ }^{18}$.

Also Georgewill OA et al., 2018 showed that three classes of phytochemicals:

- glucomoringin,

- flavonoids (quercetin and kaempferol),

- Phenolic acids which are the beneficial components of (MO) that responsible for its antioxidant properties ${ }^{19}$.
Comet assay is sensitive method best used for detection of DNA damage at the level of individual eukaryotic cell, ${ }^{20}$.

If negatively charged DNA contained breaks in the cell, DNA supercoils will relax during electrophoresis and broken ends can migrate toward the anode but if the DNA was undamaged there will not be broken ends and large size of the fragments will prevent the migration and this can be visualized by fluorescence microscope, ${ }^{21,22}$.

In the present study, comet assay in the control group showed the majority of cells as homologous discs with a very low tail moment, very low percentage of tail length and tail DNA \% indicating very limited amount of DNA damage, while in group II, tail formation was different from the control gland cells in the number of tailed cells, tail length and tail moments with a highly significant difference indicating greater DNA damage due to diabetes.

In group II the tail moment was found to be significantly increased than control group indicating increased number of DNA strand breaks and this was in agreement with (Maha El-Wassef, et al., 2012) ${ }^{23}$ who investigate the oxidative DNA damage in patients with type 2 Diabetes mellitus and found that presence of ROS and occurrence of lipid peroxidation are common in diabetic patients ${ }^{24}$. The sequence is: cellular macromolecules damage, leading to DNA and protein modification in the form of strand breaks in DNA, oxidation of guanine residues to $8-\mathrm{OHdG}$, which is an oxidized nucleoside of DNA, that considered the most frequently detected DNA lesion, ${ }^{25}$.

In group III the tail moment was found to be significantly decreased than that found in the group II indicating decrease in the amount of DNA damage and these results come in accordance with (KunalSikder, et al., 2013) who proved the antioxidant capabilities of moringa oleifera against DNA structural changes because MO directly prevents the hydroxyl radical induced DNA damage in mice lymphocytes, ${ }^{26}$. 


\section{CONCLUSION}

Moringa oleifera extract exerts a hypoglycemic effect in rats. This also underscores the potential of this herbal therapy in the management of diabetic hyperglycemia.

\section{REFERENCES}

1- Maddux BA, See W, Lawrence JC Jr., Goldfine AL, Goldfine ID, Evans JL. Protection against oxidative stress-induced insulin resistance in rat L6 muscle cells by mircomolar concentrations of alpha-lipoic acid. Diabetes 2001; 50: 404-10.

2- Stadler K. Oxidative stress in diabetes. Adv Exp Med Biol 2012; 771: 272-87.

3- Ikebukuro K, Adachi Y, Yamada Y, Fujimoto S, Seino Y, Oyaizu H. Treatment of Streptozotocin-induced diabetes mellitus by transplantation of islet cells plus bone Marrow cells via portal vein in rats. Transplantation 2002; 73 (4):512-8.

4- Hasegawa J, Hidaka H, Tateda M, Kudo T, Sagai S, Miyazaki M, et al. An analysis of clinical risk factors of deep neck infection. Auris Nasus Larynx 2011; 38: 101-7.

5- Misrha G, Singh P, Verma R, Kumar S, Srivastav S, Jha KK, Khosa RL. Traditional uses, phytochemistry and pharmacological properties of Moringa oleifera plant: an overview. Der Pharm Lett. 2011;3(2):141-164

6- A. Villarruel-López, D. A. López-de la Mora, O. D. Vázquez-Paulino, A. G. Puebla-Mora, Ma R. Torres-Vitela, L. A. Guerrero-Quiroz and K. Nuño. Effect of Moringa oleifera consumption on diabetic rats. 2018; 18(1):127

7- Bimala Patawari. Moringa_oleifera. A glossary of medicinal plants of Assam \& Meghalaya. Guwahati. N. Printers; 1992, p.87.

8- Makkar HP and Becker K. Nutrients and anti-quality factors indifferent morphological parts of the Moringa oleifera tree. J Agric Sci Cambridge 1997; 128: 311-322.

9- Dolly Jaiswal, Prashant Kumar Rai, Shikha Mehta, Sanjukta Chatterji, Surekha Shukla, Devendra Kumar Rai, Gaurav Sharma, Bechan Sharma, Shahidul khair, Geeta Watal. Role of Moringa oleifera in regulation of diabetesinduced oxidative stress. Asian Pacific Journal of Tropical Medicine 2013; 426-432.
10- Belkacemi L, Selselet-Attou G, Hupkens E, Nguidjoe E, Louchami K, Sener A\& Malaisse WJ: Intermittent Fasting Modulation of the Diabetic Syndrome in StreptozotocinInjected Rats. Int J Endocrinol 2012; 2012:962012

11- Hie M, Shimono M, Fujii K\& Tsukamoto I: Increased cathepsin $\mathrm{K}$ and tartrate-resistant acid phosphatase expression in bone of streptozotocin-induced diabetic rats. Bone 2007; 41: 1045-1050.

12- Singh N. P., McCoy M. T., Tice R. R., Schneider E. L. A simple technique for quantitation of low levels of DNA damage in individual cells. Exp. Cell Res. 175; 1988, 184-191.

13- Alok Dhawan, Mahima Bajpayee, Alok Kumar Pandey and Devendra Parmar. Protocol for the single cell gel electrophoresis / comet assay for rapid genotoxicity assessment. Developmental Toxicology Division Industrial Toxicology Research Centre.

14- Hayat MA: Principles and techniques of electron microscopy (4th Ed.). Biological applications. Van Nostrand Reinhold.2000; 4:216.

15- Chavez EM, Taylor GW, Borrell LN, Ship JA. Salivary function and glycemic control in older persons with diabetes. Oral Surg Oral Med Oral Pathol 2000; 89:305-311

16- Caldeira EJ, Garcia PJ, Minatel E, Camilli JC, Cagnon VHA. Morphometric analysis and ultrastructure of the epithelium of the oral mucosa in diabetic autoimmune NOD mice. Braz J Morphol Sci 2004; 21:197-205

17- Divi SM, Bellamkonda R, Dasireddy SK. Evaluation of antidiabetic and antihyperlipedemic potential of aqueous extract of Moringa oleifera in fructose feed insulin resistant and STZ induced diabetic wistar rats: a comparative study. Asian J Pharm Clin Res. 2012;5(1):67-72.

18- El Sadik A, Mohamed E, El Zainy A. Postnatal changes in the development of rat submandibular glands in offspring of diabetic mothers: Biochemical, histological and ultrastructural study. PLoS ONE 2018; 13(10): e0205372.

19- Georgewill OA, Georgewill UO, Nwankwoala RNP. Antiinflammatory effects of Moringa oleifera lam extract in rats. Asian Pac J Trop Med. 2010; 3 (2):133-135.

20- Tice R. R. Single cell gel/ comet assay. Guidelines for in vitro and in vivo Genetic Toxicology Testing. Environmental and Molecular Mutagenesis, 2000; 35 (3): 206- 21. 
21- Rydberg, B. The rate of strand separation in alkali of DNA of irradiated mammalian cells. Radiat. Res. 1975, 61, 274-287.

22- Kohn, K.W. and Grimek-Ewig, R.A. Alkaline elution analysis, a new approach to the study of DNA single-strand interruptions in cells. Cancer Res. 1973; 33, 1849-1853.

23- Maha El-Wassef, Gamila S. M. El-Saeed, Safinaz E. ElTokhy, Hala M. Raslan, Salwa Tawfeek, Ibrahem Siam, Sohair I. Salem. Oxidative DNA damage in patients with type 2 diabetes mellitus. Diabetologia Croatica 2012; 41-4.
24- Woods J, Young A, Gilmore L, et al. Measurement of menadione-mediated DNA damage in human lymphocytes using the comet assay. Free Radic Res 1997; 26 (2):113-124.

25- Dandona P, Thusu K, Cook S, et al. Oxidative damage to DNA in diabetes mellitus. Lancet 1996; 347: 444-445.

26- Kunal Sikder, Mahuya Sinha, Nilanjan Das, Dipeshkr Das, Sanjukta Dattaand Sanjit Dey. Moringa oleifera leaf extract prevents in vitro oxidative DNA damage. Asian J Pharm Clin Res, Vol 6, Suppl 2, 2013, 159-163. 